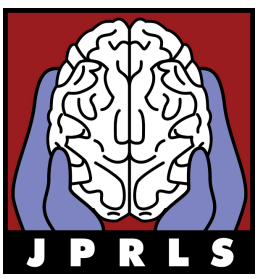

Open Access via www.jprls.org

Journal of Parkinsonism \& Restless Legs Syndrome

\title{
A comparative analysis of how Michael J. Fox and Muhammad Ali changed the world's views on Parkinson's disease
}

\author{
Ahmad Mobin* \\ Department of Health Studies, University of Toronto, Toronto, Ontario, Canada
}

\begin{abstract}
Parkinson's disease is a disabling neurodegenerative disease that affects more than 6.3 million individuals in the world, including 1.5 million Americans and more than 100,000 Canadians. The incidence of Parkinson's disease increases with age, and its prevalence is expected to double by 2030. The main motor symptoms of Parkinson's disease include resting tremor, bradykinesia, rigidity, postural instability, loss of balance and difficulty walking. Though there is no cure for Parkinson's disease, current therapies focus on improving the symptoms of this debilitating condition. Much needs to be done to promote public awareness of this condition. This review will briefly discuss the impact that Michael J. Fox and Muhammad Ali had on the world's view of Parkinson's disease.
\end{abstract}

\section{INTRODUCTION}

"Those who fight Parkinson's with knowledge always find solutions."

- Dr. Abdul Qayyum Rana

* Correspondence to: Ahmad Mobin, Department of Health Studies, University of Toronto, 1265 Military Trail, Toronto, Ontario, Canada, M1C1A4. Email: amob87@gmail.com.
Parkinson's disease (PD) has troubled mankind throughout history, and puzzled doctors for centuries. Ancient books from China and India describe patients displaying clinical features similar to what is known now as PD, in addition to tremor. It was not until 1817, when the London physician James Parkinson published his pamphlet "An Essay on the Shaking Palsy" that the first modern description of PD appeared. ${ }^{1}$ Parkinson reported on six individuals whose tremors he described as "involuntary tremulous motion, with lessened muscular power, in parts not in action and even when supported; with a propensity to bend the trunks forwards, and to pass from a walking to a running pace: the senses and intellects being uninjured." Parkinson went on to hypothesize that the disease was caused by an abnormality originating in the upper part of the spinal cord, and eventually extending to the very back end of the brain and the medulla as the disease progressed. $^{2}$ Over the years, the ability to study the brains of patients allowed researchers to identify the deterioration of dopamine within the substantia nigra region as most responsible for the onset of $\mathrm{PD} .^{3}$ In spite of these revolutionary advances in understanding of neurodegenerative disorders in the past two hundred years, a cure for this disease continues to elude the medical community. ${ }^{4}$

$\mathrm{PD}$ is a daily struggle for more than 6.3 million individuals around the world, including 1.5 million Americans, with as many as 50,000 new cases each year, and it is estimated to cost United States alone 25 billion dollars annually. ${ }^{5}$ The incidence of PD greatly increases with age from 17.4 in 100,000 individuals between 50 and 59 years of age to 93.1 in 
100,000 individuals between 70 and 79 years of age with a peak onset at age $60 .^{6}$ It is a neurodegenerative condition of the nervous system that disrupts the communication in the basal ganglia, a region that regulates movement, posture, and balance. PD is diagnosed if a patient displays two of the four following cardinal symptoms: a resting tremor (trembling of the hands or feet that occurs only when not in motion); rigidity (stiffness of the muscles); bradykinesia (slow movement, incompleteness of movement, difficulty in initiating movement, and arrest of ongoing movement); and postural instability (loss of balance and difficulty walking). ${ }^{7}$ While there is no cure for $\mathrm{PD}$, current therapies focus on alleviating the symptoms and making lifestyle changes to improve motor function. ${ }^{3}$

$\mathrm{PD}$ is endemic rather than epidemic since it is prevalent consistently worldwide instead of being demonstrated by new cases that substantially exceed what is expected based on recent experience. ${ }^{2}$ As well, PD is unrelated to race or creed, making it a global disease. Therefore, the need to educate the world and bring about social awareness is important for the efforts of providing healthcare to those with PD. ${ }^{8}$ Programs like the World Parkinson's Education Program use traditional methods to educate individuals across the world. This includes providing up-to-date literature in various languages, attempting to operate on an international scale. In addition, this program and others have used social media (i.e. Facebook, YouTube, Twitter, etc.) to help unite researchers, healthcare providers, and those who have PD in the search of a solution. Even with these efforts to reach out to the general public, nothing compares to the driving force of celebrity endorsements to convey information. Fortunately, another way in which the PD community has been able to express their message is through the advocacies of two famous celebrities, Michael J. Fox and Muhammad Ali, both of whom have been diagnosed with PD. These icons in their respective industries have had profound effects in creating social awareness and advancing PD research. This article will analyze how the PD community has benefited from the contributions of Michael J. Fox and Muhammad Ali.

\section{Michael J. FoX}

"When I disclosed my condition in 1998, I was for the most part just seeking relief from the strain... To be brutally honest, for much of that time, I was the only person in the world with Parkinson's... Going public was a difficult decision... More than a million Americans and their families were going through the same thing; some openly, some in secret due to concerns of being misunderstood and marginalized. I represented something to them, I now represented them in the minds of other people. I recognized both a responsibility to this new community as well as an opportunity to do something positive. "9

- Michael J. Fox

Michael J. Fox was born in Edmonton, Alberta, Canada on June 9, 1961. He built his acting career by often playing likeable younger characters fitting his stature and boyish looks. In the 1980s and 1990s, he was one of Hollywood's leading actors as he received many critically acclaimed awards and accolades. In 2000, at the height of his Hollywood career, he stunned the world and announced that he had been battling PD since 1991. After this, he quit acting to devote his time and energy creating optimism for those with PD. ${ }^{10}$

The public was in utter disbelief following Fox's revelation due to the common perception of PD as being a disease of the aged. He was only thirty at the time of diagnosis. What further fueled the fire of doubt was Fox's image of youthfulness. By disclosing his condition, he made society aware of the biggest misconception about PD. In fact, ten percent of PD patients are forty years old or younger. ${ }^{11}$ However, there were also some negative effects, as Fox's announcement resulted in ostracizing him and the PD community. Notable media and political personnel accused Fox of faking his symptoms and mockingly imitated them. ${ }^{12}$ Reinforcement of these negative stereotypes forced the PD community to face recurring fears of being marginalized, misunderstood, and stigmatized. Despite the risk of further ridicule, Fox had countless media appearances and wrote several books in the past ten years to raise awareness of the social burdens PD patients battle on a daily basis. He enlightened the world about the difficulty that PD patients face in integrating themselves into society, whether it be for fears of losing their jobs, embarrassment of leaving their homes, or bouts of clinical depression; a common symptom faced by forty percent of PD patients. ${ }^{13}$

In addition to his appearances in the media, Fox has been actively involved in the political scene, testifying before the US Senate on the importance of stem cell research, which is believed by many leading neurologists to be critical to the search for treatments of PD. ${ }^{14}$ Further to this, he brought up to Congress the disparity between federal funding for PD research compared with other diseases. He showed that in the mid-1990s, the National Institutes of Health were spending an estimated $\$ 2400$ per patient per year on HIV/AIDS research, \$200 on breast cancer, \$100 on prostate cancer, $\$ 78$ on Alzheimer's disease, and only 
\$34 on PD. ${ }^{9}$ This inspired him to become focused PD research. He streamlined a private foundation whose infrastructure would raise significant money, identify underfunded scientists, and provide support as quickly as possible. It is known today as the Michal J. Fox Foundation. To date, it has provided over \$104 million and has recruited 350 scientists who specialize in PD research throughout the world. Moreover, the foundation is leading the search for the first diagnostic test for PD, and exploring the genetic risk profile of the disease, along with the possibilities of applying stem cell research. Lastly, the foundation has revolutionized how scientific research is conducted, as most projects are initiated within two months of proposition, unlike some governmental institutions that may take up to twelve months to evaluate and review an application and commence research activity. ${ }^{15}$ Still, the greatest impact Fox has had on the PD community is becoming a beacon of hope for millions, and inspiring the world to keep fighting regardless of what obstacles must be faced in a lifetime.

\section{Muhammad Ali}

"When I was first diagnosed with Parkinson's, I didn't know what direction my life would take. I didn't like the idea of being dependent on medications... My shaking and soft speech were hard for me to accept in the beginning. After a while, I began to realize that how I handled my illness had an effect on other people's suffering from Parkinson's and other illnesses. Knowing that they counted on me made me realize how much they need me." 16

- Muhammad Ali

Muhammad Ali was born on January 17, 1942 in Louisville, Kentucky, USA. He started boxing at the age of 12 and the rest is history! He went on to win the Olympic gold medal in boxing at the tender age of 18, and soon afterwards boxed professionally. Ali star-rocketed through the heavy-weight division, winning his first of three championships in $1964 .{ }^{17}$ After his return to boxing in 1970, Ali went on to fight memorable bouts against Elmo Henderson, Ken Norton, George Foreman, and Joe Frazier. ${ }^{16}$ Shortly after retiring from boxing in 1981, Ali began displaying symptoms of PD. His condition was not diagnosed until three years later. ${ }^{19}$ Beloved to many throughout the world, he remained the "People's Champ" as he continues his fight against PD.

As was the case with Michael J. Fox, the public had a hard time coming to terms with Ali's PD diagnosis. In everyone's eyes, he was a man of gifted physical fitness and athleticism, supplemented by his charisma that charmed the world with whatever he wanted to say. Disclosing his condition brought an immeasurable social awareness, with people becoming more interested in learning about the illness. He also showed that even the extremely fit and healthy are susceptible to PD.

Ali recognized that more money had to be put into PD research if there was to be any hope of finding a cure. He, along with Fox, joined a panel of scientists to discuss the progress of research, as well as the failures of an initiative by Congress to boost spending on PD by $\$ 1$ billion by 2005 . The fact that the money the National Institutes of Health had allocated for this initiative would fall short by more than $\$ 100$ million for the fiscal year of 2001 motivated him to raise funds through his organization, the Muhammad Ali Parkinson Center. ${ }^{20}$ Today, the project has two locations, at Louisville and Phoenix, and they have been regarded as among America's most comprehensive PD facilities. These state-of-the-art facilities approach healthcare in a holistic manner, bringing medical, rehabilitation, social, as well as educational services and research together. The two centers have greatly benefited from the "Celebrity Fight Night", which is a fundraiser that brings together athletes, businesspeople, and entertainers. ${ }^{21}$ Besides the obvious financial support, by associating with influential and well-known individuals such as Larry King, Donald Trump, Arnold Schwarzenegger, and Barry Manilow, greater awareness and interest has been generated for PD.

Ali also used his fame to help the general society understand the difficulties PD patients encounter. Since his diagnosis twenty years ago, he has made several public appearances, written many books on his illness, held various fundraisers, traveled the world as an ambassador of peace, and has heavily immersed himself within the PD community, even going as far as inviting patients to his home to communicate their fears and concerns. ${ }^{15}$ In addition, he has worked with Michael J. Fox in advocating the importance of stem cell research.

Perhaps the greatest spectacle he provided the world was lighting the flame that opened the Centennial Olympic Games in Atlanta, showing everyone that PD has not defeated him. This imparted hope onto others to keep fighting, and showed that you can be the "Greatest of All Time" even with PD.

\section{CONCLUSION}

"People should know that scientists say of all the neurodegenerative diseases, Parkinson's is closest to a cure in our lifetime. I firmly believe this to be true." 11

- Michael J. Fox 
We are continuously uncovering new information on PD with advancements in research. This information is made readily accessible by establishments like the World Parkinson's Education Program and other organizations. In addition to the material and educational services that are available, knowledge and awareness of PD was enhanced through social mechanisms. The society's views have come a long way due to the passion, dedication, and tireless efforts of Michael J. Fox and Muhammad Ali. What was once considered an incurable disease that only old people should be concerned about has now a vastly different public perception. Fox and Ali, through their own initiatives, have brought about awareness and have advanced PD research in a remarkably similar fashion. However, the greatest contribution they have made is giving hope, optimism, comfort, and support to those with PD during a time when the world did not understand their struggles.

\section{REFERENCES}

1. Lieberman A, Fariello G. Present and future approaches to Parkison disease. Neurology 2006; 67:1-4.

2. Rosenbaum R. Understanding Parkinson's Disease. Praeger Publishers, Westport, CT 2006.

3. Pang P. Parkinson's Disease. Encyclopedia of Stem Cell Research 2008.

4. Pirich C. (2002). Neurodegenerative Disorders. Imaging Decisions MRI 2002; 6:2.

5. Gulli L, Wells K. Parkinson's Disease. The Gale Encyclopedia of Medicine. Gale, Detriot, MI 2007.
6. Bower J, Maraganore D, McDonnell S, Rocca W. Incidence and distribution of parkinsonism in Olmsted County, Minnesota, 1976-1990. Neurology 1999; 52: 1214-20.

7. Lieberman A. 100 Questions \& Answers About Parkinson Disease 2nd Edition. Jones And Bartlett , Massachusetts 2011.

8. Stern G. Did Parkinsonism occur before 1817? J Neurol Neurosurg Psychiatry 1989; 11-12.

9. Fox M. Lucky Man. Hyperion, New York, NY 2002.

10. Fox M. Newsmakers. Gale, Detroit, MI 2001.

11. Parkinson's Disease. Greenhaven Press, Detroit, MI 2009.

12. Davis P. Heroes and Pioneers - Michael J Fox. Time Magazine 2007.

13. Fox M. Always Looking Up - The Adventures of an Incurable Optimist. Hyperion, New York, NY 2009.

14. Svendsen C. Stem Cells and Parkinson's Disease: Toward a Treatment, Not a Cure. Cell Stem Cell 2008; 412-13.

15. Davidson M. Michael J. Fox Foundation. Encyclopedia of Stem Cell Research 2008.

16. Ali M, Ali H. The Soul of a Butterfly - Reflections On Life's Journey. Simon \& Schuster, New York, NY 2004.

17. Muhammad Ali - Contemporary Black Biography. Gale Biography 2006.

18. Heroes of The Year - Muhammad Ali. Life Magazine 1999; 22: 1.

19. The Guardian. National: Disease in brief: Parkinson's: Muhammad Ali and his battle. Guardian Home Pages 2009.

20. Muhammad Ali seeks more funding for Parkinson's research at U.S. Senate hearing. Jet 2002; 101(25): 22.

21. St. Joseph's Hospital and Medical Center; Muhammad Ali Parkinson Center to Expand

Growth Funded by Celebrity Fight Night. Pain \& Central Nervous System Week 2011, 25. 